\title{
Analgesic activity of angiotensin antagonists
}

\author{
Sekar Indumathy and Subramanian Kavimani
}

\begin{abstract}
Department of Pharmacology, College of Pharmacy, Mother Theresa Post Graduate and Research Institute of Health Sciences (A Govt. of Puducherry Institution) Puducherry-605006, India.
\end{abstract}

Accepted 26 January, 2011

\begin{abstract}
Angiotensin Receptor Antagonists (ARAs) are widely used compounds in various cardiovascular disorders like Hypertension, Stroke prophylaxis, Heart failure. In addition, they are approved for the treatment of Diabetic Nephropathy. It is reported to produce analgesia on intracerebro-ventricular administration that could be blocked by naloxone. Angiotensin II has been reported for its pronociceptive activity. Angiotensin receptor antagonists block the action of angiotensin II by inhibiting its binding with its receptor hence, they exerts analgesic activity. The analgesic activity of angiotensin antagonists Losartan, Irbesartan and Valsartan evaluated by tail immersion, tail flick and tail clip methods have shown significant increase in basal reaction time. Pentazocine, a kappa receptor agonist exerted a significant analgesic effect $(p<0.001)$. In comparison to control, angiotensin antagonists Losartan, Irbesartan and Valsartan show significant reduction in time for onset of writhing and also number of writhing. The \% inhibitions of writhing for Losartan, Irbesartan and Valsartan at a dose of 20 $\mathrm{mg} / \mathrm{kg}$ were 74, 68 and $73 \%$ respectively, whereas Aspirin $(100 \mathrm{mg} / \mathrm{kg}) \mathrm{has} 83 \%$ inhibition. All the three drugs have shown significant $p$ value $(p<0.001)$ which is comparable to standard control
\end{abstract}

Key words: Angiotensin antagonist, Losartan, Irbesartan and Valsartan.

\section{INTRODUCTION}

Angiotensin Receptor Antagonists (ARAs) are widely used compounds in various cardiovascular disorders like Hypertension, Stroke prophylaxis, Heart failure (Rohit et al., 2006). In addition, they are approved for the treatment of Diabetic Nephropathy (Goodman and Gilmaan, 2008). It is reported to produce analgesia on intracerebro-ventricular administration that could be blocked by naloxone. (Wang et al., 1992) Angiotensin II has been reported for its pro-nociceptive activity (Fujiyoshi et al., 1989). The aim of this study was to evaluate the analgesic effect of Angiotensin receptor antagonists.

\section{MATERIALS AND METHODS}

Albino mice of both sexes, adult (around 16 months old and weighing 25 to $35 \mathrm{~g}$ ) were selected and used. Animals were procured from the disease free small animal house. They were

${ }^{*}$ Corresponding author. E-mail: indumathy85@gmail.com. Tel: 9488820614. acclimatized to the laboratory conditions for 5 days. They were kept in sufficient polypropylene cages under controlled temperature and humidity. The animals had free access to food and water and were housed under standard light-dark cycle (12 h each). All the experiments were carried out during day time from 0900 to $1600 \mathrm{~h}$. Losartan potassium-USP (Simlan Laboratories Ltd., Mumbai), Irbesartan-USP (Hetero labs Itd., Andra Pradesh) Valsartan - USP (Hetero labs Itd., Andra Pradesh), Fortwin (Pentazocine $30 \mathrm{mg} / \mathrm{ml}$ Ranbaxy laboratories Ltd., Ahmadabad.), Ecosprin (Aspirin 150 $\mathrm{mg} / \mathrm{tab}$ Accent pharma, Jammu). All the drugs were injected intraperitoneally (i.p.) and volume of injection was made $1 \mathrm{ml} / 100 \mathrm{~g}$ body weight of the mouse. All the drugs were dissolved in distilled water except Valsartan (made suspension with $0.5 \%$ Carboxy Methyl Cellulose [CMC]) and the analgesic activity was evaluated using the following methods (thermal, physical and chemical methods).

\section{Thermal method}

\section{Tail immersion method}

Albino mice were selected by immersing the tail in hot water at $55 \pm$ $2^{\circ} \mathrm{C}$ and the basal reaction time was noted. The animals that show a positive response within $5 \mathrm{~s}$ (that is) withdrawal of tail clearly out of water were selected and they were divided into eight groups, five animals in each group. Pentazocine ( $5 \mathrm{mg} / \mathrm{kg}$ i.p.) was used as 
positive control, the test drugs Losartan and Irbesartan was given in two doses by i.p. The test drug Valsartan alone made suspension with $0.5 \% \mathrm{CMC}$ and was given in two doses by i.p. route. Group I served as vehicle control, $0.5 \% \mathrm{CMC}$ was given. Observations were made up to 90 min after the administration of the test compounds and standard drug (Kulkarni, 2007; Ghosh, 2003; Yu-Ling et al., 2003).

\section{Tail flick method}

Albino mice were divided into eight groups of 5 animals in each group. Pentazocine ( $5 \mathrm{mg} / \mathrm{kg}$ i.p.) was used as positive control, the test drugs Losartan and Irbesartan were given in two doses by i.p. The test drug Valsartan made suspension with $0.5 \%$ carboxy methyl cellulose (CMC) and given in two doses by i.p. administration. Group I served as vehicle control, 0.5\% CMC was given.

The animals were held in suitable restrainer with the tail protruding out. A cut off period of 10 to $12 \mathrm{~s}$ was given to prevent damage to the tail. The tail of the mouse was placed on the hot wire (5.35 ampere) at a distance of $1 \mathrm{~cm}$ and the time taken by the mouse to flick its tail from the hot source was taken as the Basal Reaction Time (BRT). For each mouse 3 to 5 Basal reaction times were noted. Basal reaction times were observed at $0,30,60$ and 90 min respectively. Observations were made up to 90 min after the administration of the test compounds and standard drug and its activities were evaluated (Kulkarni, 2007; Ghosh, 2003; Yu-Ling et al., 2003).

\section{Phsical method}

\section{Tail clip method}

Albino mice were selected by applying a metal clip to the base of tail. The animals which did not show efforts to dislodge the clip within $15 \mathrm{~s}$ were not used for the experiments. Animals were divided into eight groups, five animals in each. Group I served as vehicle control, $0.5 \%$ carboxy methyl cellulose (CMC) $(10 \mathrm{ml} / \mathrm{kg}$ i.p.) was given. Group II served as positive control Pentazocine $(5 \mathrm{mg} / \mathrm{kg}$ i.p.) was given. Groups III and IV received Losartan $10 \mathrm{mg}$ and 20 $\mathrm{mg} / \mathrm{kg}$ i.p respectively. Groups V and VI received Irbesartan $10 \mathrm{mg}$ and $20 \mathrm{mg} / \mathrm{kg}$ i.p respectively. Groups VII and VIII received Valsartan $10 \mathrm{mg}$ and $20 \mathrm{mg} / \mathrm{kg}$ i.p. (made suspension with $0.5 \%$ $\mathrm{CMC}$ ) respectively. The tail clip was applied at $0,30,60$ and $90 \mathrm{~min}$ after drug administration and the basal reaction time was noted (Kulkarni, 2007; Ghosh, 2003; Yu-Ling et al., 2003)

\section{Chemical method}

\section{Acetic acid induced writhing}

Albino mice of both sexes weighing 25 to $35 \mathrm{~g}$ were selected and were divided into five groups, each group containing five animals. Writhing is induced by intraperitoneal administration of $1 \% \mathrm{v} / \mathrm{v}$ of acetic acid in $0.9 \%$ sodium chloride $(1 \mathrm{ml} / 100 \mathrm{~g}$ i.p.). Aspirin 100 $\mathrm{mg} / \mathrm{kg}$ was used as standard drug. Group I served as vehicle control, $0.5 \%$ carboxy methyl cellulose (CMC) $(10 \mathrm{ml} / \mathrm{kg}$ i.p.) was given. Group II served as positive control Aspirin (100 mg/kg i.p.) (made suspension with $0.5 \%$ CMC)was given. Group III received Losartan $20 \mathrm{mg} / \mathrm{kg}$ i.p., Group IV Irbesartan $20 \mathrm{mg} / \mathrm{kg}$ i.p and Group V received Valsartan $20 \mathrm{mg} / \mathrm{kg}$ i.p. (made suspension with $0.5 \% \mathrm{CMC}$ ) respectively. After $30 \mathrm{~min}$ of drug administration, animals were challenged with $1 \% \mathrm{v} / \mathrm{v}$ of acetic acid in $0.9 \%$ sodium chloride (1 ml/100 g i.p.).
Immediately after injection of algic compound, each animal was isolated in an individual box $(25 \times 25 \times 50 \mathrm{~cm})$. The time of onset of writhing action and the no. writhing were observed for $15 \mathrm{~min}$ after the onset of writhing, counted and compared to the response with the control group (Kulkarni, 2007; Ghosh, 2003; Yu-Ling et al., 2003; Ramasamy et al., 1998; Dongmo et al., 2005). "Percentage of writhings inhibition $=$ mean value of control group writhings mean value of control group writhings/mean value of control group writhings $X 100$ ".

\section{RESULTS}

\section{Tail immersion method}

The analgesic activity of angiotensin antagonists Losartan, Irbesartan and Valsartan evaluated by tail immersion method showed significant increase in basal reaction time. Pentazocine, a kappa receptor agonist exerted a significant analgesic effect $(p<0.001)$ at $30 \mathrm{~min}$. Losartan at both the doses of 10 and $20 \mathrm{mg} / \mathrm{kg}$ showed significant analgesic effect $(p<0.001)$ at $30 \mathrm{~min}$. Irbesartan and Valsartan showed significant analgesic effect $(p<0.01)$ at 60 min. Results were given in Table 1.

\section{Tail flick method}

The analgesic activity of angiotensin antagonists Losartan, Irbesartan and Valsartan evaluated by tail flick method showed significant increase in basal reaction time from 0 to $60 \mathrm{~min}$. Losartan and Irbesartan at 10 $\mathrm{mg} / \mathrm{kg}$ showed $p$ value less than $0.01(p<0.01)$ at $60 \mathrm{~min}$. Basal Reaction Time (BRT) (mean \pm SEM) at $0 \mathrm{~min}$ is $3.2 \pm 0.27$, and $5.6 \pm 0.49$ to $7.4 \pm 0.51$ and $6.8 \pm 0.2 \mathrm{~s}$ at 60 min. Valsartan $(10 \mathrm{mg} / \mathrm{kg})$ showed $\mathrm{p}<0.05$. Losartan, Irbesartan and Valsartan showed very significant effect $(p<0.001)$ at a dose of $20 \mathrm{mg} / \mathrm{kg}$ at $60 \mathrm{~min}$. BRT (mean \pm SEM) are increased from $2.8 \pm 0.41,5.4 \pm 0.25$ and $4.4 \pm 0.49 \mathrm{~s}$ at $0 \mathrm{~min}$ to $8.6 \pm 0.49,8.2 \pm 0.37$ and $14.8 \pm 1.1 \mathrm{~s}$ at $60 \mathrm{~min}$. Pentazocine, a kappa receptor agonist exerted a significant analgesic effect $(p<0.001)$ at $60 \mathrm{~min}$. The analgesic activity of angiotensin antagonist is comparable to that of standard drug using flick method. Results were given in Table 2.

\section{Tail clip method}

The analgesic activity of angiotensin antagonists Losartan, Irbesartan and Valsartan evaluated by tail clip method did not show very significant increase in basal reaction time comparable to that of tail flick and immersion methods. However, Losartan at a dose of $20 \mathrm{mg} / \mathrm{kg}$ shows $p$ value less than $0.01(p<0.01)$. Pentazocine, a kappa receptor agonist exerted a significant analgesic effect $(p<0.001)$ at $30 \mathrm{~min}$. The analgesic activity of angiotensin antagonist is comparable to that of standard drug using clip method. Results were given in Table 3. 
Table 1. Analgesic activity of angiotensin antagonists (Tail immersion method).

\begin{tabular}{|c|c|c|c|c|c|c|}
\hline \multirow{2}{*}{ Group } & \multirow{2}{*}{ Treatment } & \multirow{2}{*}{ Dose (ml/Kg i.p.) } & \multicolumn{4}{|c|}{ Basal reaction time $(\mathrm{s})$ (mean \pm SEM) } \\
\hline & & & $0 \mathrm{~min}$ & $30 \mathrm{~min}$ & $60 \mathrm{~min}$ & $90 \mathrm{~min}$ \\
\hline Group I & $0.5 \% \mathrm{CMC}$ & 10 & $1.24 \pm 0.11$ & $1.12 \pm 0.11$ & $1.50 \pm 0.12$ & $1.13 \pm 0.10$ \\
\hline Group II & Pentazocine & 5 & $1.77 \pm 0.07$ & $5.31 \pm 0.33^{*}$ & $3.11 \pm 0.14$ & $1.97 \pm 0.11$ \\
\hline Group III & Losartan & 10 & $1.53 \pm 0.10$ & $3.38 \pm 0.19^{*}$ & $3.33 \pm 0.48$ & $2.73 \pm 0.50$ \\
\hline Group IV & Losartan & 20 & $1.65 \pm 0.11$ & $3.69 \pm 0.12^{*}$ & $3.41 \pm 0.25$ & $2.75 \pm 0.28$ \\
\hline Group V & Irbesartan & 10 & $1.11 \pm 0.14$ & $1.88 \pm 0.11$ & $2.37 \pm 0.09^{*}$ & $1.8 \pm 0.08$ \\
\hline Group VI & Irbesartan & 20 & $1.75 \pm 0.16$ & $3.91 \pm 0.69$ & $4.06 \pm 0.69^{\star \star}$ & $3.35 \pm 0.46$ \\
\hline Group VII & Valsartan & 10 & $1.63 \pm 0.14$ & $2.08 \pm 0.14$ & $3.89 \pm 0.57^{\star \star}$ & $3.01 \pm 0.4$ \\
\hline Group VIII & Valsartan & 20 & $1.57 \pm 0.13$ & $2.43 \pm 0.48$ & $3.11 \pm 0.35^{\star *}$ & $3.03 \pm 0.66$ \\
\hline
\end{tabular}

${ }^{*} \mathrm{P}<0.001$ vs. normal control, ${ }^{*} \mathrm{P}<0.01$ vs. normal control, $n=5$.

Table 2. Analgesic activity of angiotensin antagonists (tail flick method).

\begin{tabular}{|c|c|c|c|c|c|c|}
\hline \multirow{2}{*}{ Group } & \multirow{2}{*}{ Treatment } & \multirow{2}{*}{ Dose (ml/Kg i.p) } & \multicolumn{4}{|c|}{ Basal reaction time $(s)($ mean \pm SEM) } \\
\hline & & & $0 \mathrm{~min}$ & $30 \mathrm{~min}$ & $60 \mathrm{~min}$ & $90 \mathrm{~min}$ \\
\hline Group I & $0.5 \% \mathrm{CMC}$ & 10. & $5.4 \pm 0.51$ & $5 \pm 0.45$ & $5 \pm 0.45$ & $5 \pm 0.310$ \\
\hline Group II & Pentazocine & 5. & $3.4 \pm 0.68$ & $9.4 \pm 0.24$ & $15.4 \pm 1.6^{*}$ & $5.8 \pm 0.8$ \\
\hline Group III & Losartan & 10 & $3.2 \pm 0.37$ & $6 \pm 0.32$ & $7.4 \pm 0.51^{* *}$ & $4.2 \pm 0.37$ \\
\hline Group IV & Losartan & 20 & $2.8 \pm 0.41$ & $7.2 \pm 0.49$ & $8.6 \pm 0.49^{*}$ & $4.4 \pm 0.24$ \\
\hline Group V & Irbesartan & 10 & $5.6 \pm 0.49$ & $6 \pm 0.32$ & $6.8 \pm 0.2^{* *}$ & $5 \pm 0.32$ \\
\hline Group VI & Irbesartan & 20 & $5.4 \pm 0.25$ & $6.8 \pm 1.6$ & $8.2 \pm 0.37^{*}$ & $3.8 \pm 0.2$ \\
\hline Group VII & Valsartan & 10 & $3.8 \pm 0.58$ & $7.8 \pm 1 \psi_{*}$ & $7.6 \pm 1.21$ & $5.2 \pm 0.66$ \\
\hline Group VIII & Valsartan & 20 & $4.4 \pm 0.49$ & $8 \pm 0.84$ & $14.8 \pm 1.1^{*}$ & $4.6 \pm 0.25$ \\
\hline
\end{tabular}

${ }^{*} \mathrm{P}<0.001$ vs. normal control, ${ }^{* *} \mathrm{P}<0.01$ vs normal control, ${ }^{{ }^{*}} \mathrm{P}<0.05$ vs. normal control, $\mathrm{n}=5$.

Table 3. Analgesic Activity of angiotensin antagonists (tail clip method).

\begin{tabular}{|c|c|c|c|c|c|c|}
\hline \multirow{2}{*}{ Groups } & \multirow{2}{*}{ Treatment } & \multirow{2}{*}{ Dose (ml/Kg i.p.) } & \multicolumn{4}{|c|}{ Basal reaction time $(\mathrm{s})$ (mean $\pm \mathrm{SEM})$} \\
\hline & & & $0 \min$ & $30 \mathrm{~min}$ & $60 \mathrm{~min}$ & $90 \mathrm{~min}$ \\
\hline Group I & $0.5 \% \mathrm{CMC}$ & 10 & $1.32 \pm 0.04$ & $1.34 \pm 0.04$ & $1.28 \pm 0.02$ & $1.32 \pm 0.04$ \\
\hline Group II & Pentazocine & 5. & $1.34 \pm 0.05$ & $14.19 \pm 2.96$ & $11.43 \pm 1.62^{*}$ & $8.94 \pm 1.31$ \\
\hline Group III & Losartan & 10 & $1.19 \pm 0.06$ & $4.68 \pm 1.12^{\star \star *}$ & $2.87 \pm 0.6$ & $1.94 \pm 0.2$ \\
\hline Group IV & Losartan & 20 & $1.26 \pm 0.05$ & $5.49 \pm 1.19^{\star *}$ & $4.18 \pm 1.02$ & $2.84 \pm 0.59$ \\
\hline Group V & Irbesartan & 10 & $2.21 \pm 0.29$ & $5.7 \pm 2.49$ & $4.1 \pm 1.16^{\star \Psi}$ & $2.69 \pm 0.45$ \\
\hline Group VI & Irbesartan & 20 & $1.8 \pm 0.1$ & $2.7 \pm 0.13$ & $3.76 \pm 0.15^{\star}$ & $2.95 \pm 0.23$ \\
\hline Group VII & Valsartan & 10 & $1.29 \pm 0.5$ & $3.1 \pm 1.79$ & $5.6 \pm 2.72^{\psi}$ & $2.31 \pm 0.96$ \\
\hline Group VIII & Valsartan & 20 & $1.43 \pm 0.42$ & $1.71 \pm 0.49$ & $2.01 \pm 0.5^{\Psi}$ & $1.48 \pm 0.43$ \\
\hline
\end{tabular}

${ }^{*} \mathrm{P}<0.001$ vs. normal control, ${ }^{* *} \mathrm{P}<0.01$ vs. normal control, ${ }^{{ }^{*}} \mathrm{P}<0.05$ vs. normal control, ${ }^{\psi} \mathrm{P}<0.5$ vs. normal control, ${ }^{* * *} \mathrm{P}<0.02$ vs. normal control, $\mathrm{n}=$ 5.

\section{Acetic acid induced writhing}

The vehicle control which was treated with $1 \%$ acetic acid i.p. produces onset of writhing at $2.21 \pm 0.08 \mathrm{~min}$ and no. of writhings were $75 \pm 1.92$, whereas the group pretreated with Aspirin, angiotensin antagonist Losartan, Irbesartan and Valsartan produces onset of writhing at $12.46 \pm 0.8$, $6.58 \pm 0.19,4.55 \pm 0.25$ and $9.52 \pm 0.25 \mathrm{~min}$ respectively (that is) the time for onset of writhing was increased. At
15 min the number of writhing reduced to $12.4 \pm 0.92$, $19.4 \pm 1.08,24.2 \pm 1.57$ and $20.4 \pm 0.92$ respectively. In comparison to control, angiotensin antagonist Losartan, Irbesartan and Valsartan shows significant reduction in time for onset of writhing and also no. of writhing. The \% inhibitions of writhing for Losartan, Irbesartan and Valsartan at a dose of $20 \mathrm{mg} / \mathrm{kg}$ were 74,68 and $73 \%$ respectively, whereas Aspirin (100 mg/kg) has $83 \%$ inhibition. All the three drugs showed significant $p$ value 
Table 4. Analgesic activity of angiotensin antagonists (acetic acid induced writhing).

\begin{tabular}{llcccc}
\hline \multirow{2}{*}{ Groups } & \multirow{2}{*}{ Treatment } & $\begin{array}{c}\text { Dose } \\
\text { (ml/kg i.p.) }\end{array}$ & \multicolumn{2}{c}{ Acetic acid induced writhing (mean \pm SEM) } & Time for onset of writhing (min) \\
\cline { 3 - 5 } & & 10 & $2.21 \pm 0.08$ & Total no. of writhings (in 15 min) & of writhings \\
\hline Group I & $0.5 \%$ CMC & 100 & $12.46 \pm 0.8^{*}$ & $75 \pm 1.92$ & - \\
Group II & Aspirin & 20 & $6.58 \pm 0.19^{*}$ & $12.4 \pm 0.92^{*}$ & 83 \\
Group III & Losartan & 20 & $4.55 \pm 0.25^{*}$ & $19.4 \pm 1.08^{*}$ & 74 \\
Group IV & Irbesartan & 20 & $24.2 \pm 1.57^{*}$ & 68 \\
Group V & Valsartan & 20 & $9.52 \pm 0.25^{*}$ & $20.4 \pm 0.92^{*}$ & 73 \\
\hline
\end{tabular}

${ }^{*} \mathrm{P}<0.001$ vs normal control, $\mathrm{n}=5$.

$(p<0.001)$ which is comparable to standard control. Results were given in Table 4.

\section{DISCUSSION}

The present study suggests that, angiotensin receptor blockers Losartan, Irbesartan and Valsartan at the doses of 10 and $20 \mathrm{mg} / \mathrm{kg}$ possesses analgesic activity. Pain is the major problem because majority of tissues and organs are innerved by special sensory receptors (nociceptors) connected to primary afferent nerve fibres of different diameters. Various neurotransmitters found in the dorsal horn of the spinal cord may be involved in pain modulation. These include amino acid such as glutamate and $y$-aminobutyric acid (GABA), monoamines such as Nor-epinephrine (NA) and 5 -hydroxy tryptamine (5-HT) and certain peptide molecule, of which the opioid peptides are the most important (Walker et al., 2003). Other neurotransmitters include histamine, acetyl choline and prostaglandins. Under normal conditions, pain is associated with electrical activity in small diameter primary afferent fibres of peripheral nerves. These nerves have sensory endings in peripheral tissues, and are activated by stimuli of various kinds (mechanical, thermal, chemical) (Rang et al., 2001).

In this study, the Angiotensin receptor antagonists were evaluated employing some pain models like thermal (tail flick and tail immersion), mechanical (tail clip) and chemical (acetic acid induced writhing). In all models, it possessed significant analgesic activity at high dose (20 $\mathrm{mg} / \mathrm{kg}$ ), in tail flick method it possessed dose dependent increase in analgesic activity. Evidence also exists for the involvement of $\mathrm{Ca}^{2+}$ in peripheral mechanisms mediated at the nociceptors level. The intraplantar administration of A23187 evokes hyperalgesia in rats that is potentiated by methylxanthines and antagonized by verapamil, $\mathrm{La}^{3+}$ or morphine, thus indicating that the hyperalgesic effect of the $\mathrm{Ca}^{2+}$ ionophore depends on the activity of adenylate cyclase on peripheral nociceptors. Angiotensin antagonists may possess analgesic activity by increasing pain threshold (mechanical and thermal model) or by decreasing synthesis of nociceptive neurotransmitter (chemical model). Drugs show significant effect on a viscero somatic model (tonic pain) reflected in a significant reduction of the acetic acid induced abdominal writhes. The abdominal writhing induced by acetic acid involves the production and release of arachidonic acid metabolite via cyclooxygenase (COX) and PG biosynthesis (Ferreira et al., 1979; Elisabetsky et al., 1995; Ito et al., 2001). Activation of $\mathrm{AT}_{1}$ receptor with Ang II also increases Ca influx; therefore, blockage may possesed analgesic activity.

At low doses, it does not have any effect on nociception at administration while chronic administration produces anti nociceptive effect (Takai et al., 1996), but our findings suggests that, angiotensin antagonists Losartan, Irbesartan and Valsartan at high dose (20 $\mathrm{mg} / \mathrm{kg}$ ) possessed significant analgesic activity. Apart from antihypertensive property, they also possessed analgesic activity and it was proven by various pain models in mice. However, further clinical studies have to be carried out to find its extent of analgesic activity in normal, as well as hypertensive volunteers. Hence, they may prevent the use of multidrug in hypertensive patient for pain relieving purpose.

\section{REFERENCES}

Dongmo AB, Nguelefack T, Lacaille DMA (2005). Anti nociceptive and anti inflammatory activities of Acacia pennata wild (mimosaceae). J. Ethanopharmacol., 98: 201-206.

Elisabetsky E, Amador TA, Albuquerque RR, Nunes DS, Carvalhi ACR (1995). Analgesic activity of Psychotria colorata muell. Arg. alkaloids. J. Ethanopharmacol., 48: 77-83.

Ferreira SH, Nakamura M (1979). Prostaglandin hyperalgesia: the peripheral analgesic activity of morphine, enkephalins and opioid antagonists. Prostaglandins 18: 191-200.

Fujiyoshi T, Hayashi T, Ohishi S, Kuwashima M, lida H, Drozen M, Taniguchi N,lkeda K, Ohishi $\mathrm{H}$ (1989). Kaolin induced writhing in mice, a new model of possible bradykinin induced assessment of analgesic agents. Agents Actions 27: 332-334.

Ghosh MN (2003). Evaluation of Analgesic activity. Fundamentals of Experimental Pharmacology, $2^{\text {nd }}$ edition Delhi: J.Sinha (Scientific Book Agency), pp.145-146.

Goodman G (2008). Renin and angiotensin. The Pharmacological basis of therapeutics, $11^{\text {th }}$ edition: MacGraw - Hill companies, pp.511-527.

Ito S, Okuda Ashitaka E, Minami T (2001). Central and peripheral roles of prostaglandins in pain and their interactions with novel neuropeptides nociception and nocisattin. Neurosci. Res., 42: 299332.

Kulkarni SK (2007). Evaluation of analgesic activity. Handbook of experimental pharmacology, $3^{\text {rd }}$ edition Delhi: vallabh Prakashan , pp. 123-127.

Ramasamy S, Reddy PRMK, Shewade DG (1998). Clonidine induced 
anti- nociception:biochemical and celluler evidences on the MAO Indian. J. Pharmacol., pp. 30-33.

Rang HP, Dale MM, Ritter JM (2001).The vascular System .Text book of Pharmacology, $4^{\text {th }}$ edition New Delhi: Churchill Livingstone (Harcourt publishers limited), pp. 298-311.

Rohit CRUS, Gopala kHN (2006). Effects of captopril and losartan on thermal and chemical induced pain in mice. Indian. J. Physiol. Pharmacol., 50(2): 169-174.

Takai S, Song K, Tanaka T, Okunishi H, Miyazaki M (1996). Antinociceptive effect of angiotensin converting enzyme inhibitors and Angiotensin II receptor antagonist in mice. Life Sci., 59 (21): 331 336.
Walker R, Edwards C (2003). Clinical pharmacy and therapeutics $3^{\text {rd }}$ edition Churchill Livingstone, p. 465.

Wang JF, sun XJ, yang HF, Ren MF, Han JS (1992). Mobilization of calcium from intracellular stores as possible mechanism underlying the anti-opioid effect of Angiotensin II. Neuropeptides., 22: 219-222.

Yu-Ling HO, Kuo-Ching K, Huei-Yann T, Fu-Yu C, Yuan-Shiun C (2003). Evaluation of Antinociceptive, Anti-inflammatory and Antipyretic Effects of Strobilanthes cusia Leaf Extract in Male Mice and Rats. AJCM., 31(1): 61-69. 